\title{
THE INFLUENCE OF NON-CONVENTIONAL SINTERING METHODS \\ ON GRAIN GROWTH AND PROPERTIES OF ALUMINA SINTERS
}

\author{
WPŁYW NIEKONWENCJONALNYCH METOD SPIEKANIA \\ NA ROZROST ZIAREN I WŁAŚCIWOŚCI \\ SPIEKÓW TLENKU GLINU
}

\author{
Marcin ROZMUS ${ }^{1}$, Piotr PUTYRA ${ }^{1}$, Paweł FIGIEL ${ }^{1}$
}

\begin{abstract}
The aim of this study was to obtain ceramic alumina materials by using the conventional free sintering process, $2.45 \mathrm{GHz}$ microwave sintering and spark plasma sintering (SPS). Technical produced by Alcoa and ultra-pure alumina produced by Atlantic Equipment Engineers was used to obtain specimens. After sintering, the materials were subjected to studies of their physical and mechanical properties and carried out SEM observation using scanning electron microscope. The effect of temperature and time of sintering on the density, Young's modulus and Vickers hardness of $\mathrm{Al}_{2} \mathrm{O}_{3}$ ceramics was determined. Mechanical and physical properties of the obtained materials were compared between the methods of sintering. On the basis of images from scanning electron microscope was performed quantitative analysis allows to determine the degree of grain growth of alumina after sintering. Our calculations were based on classic formulas of stereology for single-phase structure. The use of advanced sintering processes allowed to receive alumina ceramic materials with good mechanical and physical properties at the time of one minute for microwave sintering to ten minutes for spark plasma sintering. The non-conventional methods for sintering ceramics primarily comprises spark plasma sintering and microwave sintering. Microwave and SPS sintering methods did not prevent grains growth of $\mathrm{Al}_{2} \mathrm{O}_{3}$, and even resulted in their growth.
\end{abstract}

Keywords: ceramic alumina materials, non-conventional sintering methods, grain growth, microstructure investigations

Streszczenie: Celem przeprowadzonych badań było otrzymanie spieków tlenku glinu przez zastosowanie konwencjonalnego spiekania swobodnego, mikrofalowego przy częstotliwości mikrofal $2,45 \mathrm{GHz}$ oraz spiekania metodą SPS. Do otrzymywania spieków zastosowano techniczny proszek $\mathrm{Al}_{2} \mathrm{O}_{3}$ produkowany przez Alcoa oraz ultraczysty proszek produkowany przez Atlantic Equipment Engineers. Otrzymane spieki były przygotowywane do badań właściwości fizyko-mechanicznych oraz przeprowadzenia obserwacji mikrostrukturalnych przy zastosowaniu skaningowej mikroskopii elektronowej. Określono wpływ temperatury 
i czasu spiekania na gęstość, moduł Younga oraz twardość Vickersa ceramiki $\mathrm{Al}_{2} \mathrm{O}_{3}$. Właściwości fizyko-mechaniczne otrzymanych spieków zostały porównane pomiędzy zastosowanymi metodami spiekania. Na podstawie obserwacji SEM wykonano ilościowe analizy i obliczenia pozwalające na określenie stopnia rozrostu ziaren tlenku glinu po spiekaniu. Nasze obliczenia były oparte na klasycznych wzorach stereologicznych dla monofazowej struktury. Zastosowanie zaawansowanych procesów spiekania pozwoliło otrzymać spieki tlenku glinu o dobrych właściwościach fizyko-mechanicznych podczas jednej minuty spiekania mikrofalowego i dziesięciu minut dla spiekania SPS. Niekonwencjonalne metody spiekania obejmują głównie metodę SPS oraz metodę mikrofalową. Metody spiekania mikrofalowego oraz SPS nie zapobiegły rozrostowi ziaren $\mathrm{Al}_{2} \mathrm{O}_{3}$, a wręcz przeciwnie wpłynęły na ich rozrost.

Słowa kluczowe: spieki tlenku glinu, niekonwencjonalne metody spiekania, rozrost ziaren, badania mikrostruktury

\section{INTRODUCTION}

Alumina ceramic possesses high refractory capability, good wear resistance and chemical stability. Its application as a structural material, however, is limited by its low fracture toughness which nearly can not reduce stress concentration by application resulting from a surface defect or internal defect [1]. In recent years, is observed rapid development of new methods of sintering, based on certain physical phenomena, which have not yet been (microwave, electrical discharges) and finding new uses for existing sintering techniques (High Pressure - High Temperature). Application of new sintering methods allows significantly reduces the time and/or reduction of process temperature. Shorter sintering time and external pressure should result changes in the microstructure of obtained materials, compared to materials sintered by conventional methods.

\subsection{FREE SINTERING}

The basic technique for the preparation of oxide materials is conventional method of sintering. The sintering temperature for alumina densification usually increases with the increase its purity. If high purity alumina powders are prepared by the traditional sintering method, the sintering temperature should be above $1600^{\circ} \mathrm{C}$ to get a dense alumina sintered body [2]. During the sintering of a powder compact, both densification and grain growth occur simultaneously. Grain growth is the process by which the mean grain size increases continuously during sintering without the change in grain-size distribution. As the mean grain size increases, it is obvious that some grains must shrink. Because grain growth of alumina is sensitive to the sintering temperature, abnormal grain growth in alumina would occur final stage of densification if the sintering temperature was too high. Which would have a great influence on the flexural strength and wear resistance of alumina. It is well known that the flexural strength and wear resistance of pure alumina increases with decreasing the grain size [3].

\subsection{MICROWAVE SINTERING}

The microwave technique for sintering of various ceramic materials is one of advanced methods of sintering. There are many obvious advantages of volumetric heating and efficient 
transfer of energy in microwave processing. In conventional sintering methods thermal radiation received on the surface of the ceramic component reaches the core by thermal conduction producing high temperature gradients and stresses. Microwave sintering, also in presence of an electromagnetic field, exhibit the tendency of a dielectric material to couple with the microwave resulting in the generation of heat within. Use of microwaves allows transfer of energy directly into the materials, where it is converted to heat through absorption mechanism such as ionic conduction, dipole relaxation, and photon-phonon interaction. The technique generally uses a frequency of $2.45 \mathrm{GHz}$ resulting in relatively rapid heating rates with uniform grained microstructures and has been employed for the sintering of a wide variety of ceramics ranging from dielectric materials to transparent ceramics [4]. In the case of sintering, the materials with low absorption microwave radiation (high coefficient reflectance) should be heated using materials absorbing microwave radiation, i.e. susceptors [5]. During the process of microwave sintering there are difficulties in temperature measurement. This measurements using a thermocouple may cause changes in the predicted field pattern, which instead of being uniform, is distorted and changes abruptly near the thermocouple tip. Such local variations in the electric-field intensity cause even larger variations in the locally absorbed power density, which is proportional to the square of electric-field intensity. Power deposition increases sharply near the thermocouple tip, causing increased localized heating results and possibly leading to thermal runaway and enhanced thermal gradients. E. Pert and others showed that when microwaves are present during heating, the thermocouple can reach $>150^{\circ} \mathrm{C}$ higher than the pyrometer, which is mainly due to a field enhancement effect [6]. This indicated that the presence of the thermocouple within or near the sample revealed a strong effect on the evolution of the temperature in the sample during microwave processing. The use of optical pyrometry or optical-fiber thermometry gives good measurements results of temperature.

\subsection{SPARK PLASMA SINTERING}

SPS technology enables to carry out the sintering process for materials at lower temperature and in a shorter time than that of the conventional sintering processes. This increase in efficiency is because, in SPS, it is expected that the high electric pulse power will generate plasma in the gaps or at the contact point between powder particles, thereby cleaning powder surfaces (surface treatment) and increasing diffusivity at the physically contacted regions between particles [7]. Figure 1 shows the basic configuration of a typical SPS system. Figure 2 illustrates how pulse current flows through powder particles inside the SPS sintering die [8]. However, the sintering mechanism of SPS has not been clearly understood so far. SPS has certainly shown the ability to achieve highly compacted bulk materials, thanks to direct electric discharge during the processes [9].

The aim of this study is to obtain ceramic alumina materials by the microwave, spark plasma sintering and the conventional free-sintered methods. Mechanical and physical properties of the obtained materials will be compared between the methods of sintering. 

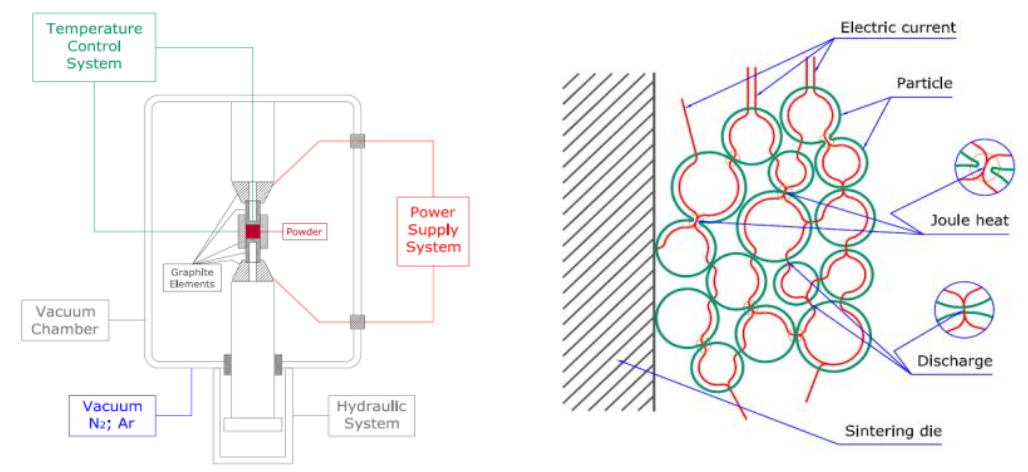

Figure 1. SPS system configuration [8]

Figure 2. Pulsed current flow through powder particles [8]

\section{EXPERIMENTAL DETAILS}

\subsection{MATERIALS AND PROCEDURE}

The following commercially available submicrometer alumina powders were used as base powders:

- technical CT3000-SG, produced by Alcoa, USA - measured average grain size: $0.48 \mu \mathrm{m}-$ mixture ,I"

- ultra-pure Al-600, produced by AEE Atlantic Equipment Engineers, USA (99.99\% purity) - measured the average grain size: $1.68 \mu \mathrm{m}$ - mixture „II”

Particle size distribution for alumina powders was measured by the CP3 (Shimadzu) centrifugal particle size analyzer.

The powder mixtures were prepared by mixing the appropriate powders in isopropanol with the addition of $0.5 \%$ mass polyethylene glycol as a dispersive agent using the colloid mill. After milling, the powder mixtures were dried and granulated. For conventional free-sintering and microwave sintering samples of the size $16.5 \times 16.5 \times 6 \mathrm{~mm}$ were formed by uniaxial pressing in the steel matrix at pressure of $130 \mathrm{MPa}$. Next all compacts were cold isostatic pressed in the hydraulic press at pressure of $250 \mathrm{MPa}$. For remove of the dispersive agent the compacts were dried at $225^{\circ} \mathrm{C}$ for 48 hours.

The next step in the process consist of conventional sintering, microwave and SPS sintering of received green bodies. The equipments for sintering alumina ceramics are shown in Figure 3. Compacts were free sintered with programmed temperature increases from 1615 to $1665^{\circ} \mathrm{C}$ in the HT $16 / 18$ Nabertherm electric furnace in air atmosphere. Another compacts were microwave sintered in a furnace at $2.45 \mathrm{GHz}$ in MKH-4.8 Linn High Therm GmbH. The manual system control of sintering parameters was used during process. Four magnetrons were used operating at $50-60 \%$ at their full power. The sintered sample was placed in the retort of porous alumina and surrounded by $\mathrm{SiC}$ susceptors to initiate heating. The alumina retort with the sintered samples is presented in Figure 4.

This was found to be essential in minimizing the thermal gradients within the sample. As temperature control was used the optical pyrometer able to work above $800^{\circ} \mathrm{C}$. To the point when pyrometer is capable of measuring temperature, the increase of power magnetrons was 
carried out very carefully to prevent excessive overheating of susceptors and the sintered sample. The samples were sintered at temperature about $1620^{\circ} \mathrm{C}$ for one minute duration of process.

To perform SPS sintering of starting powder mixtures of technical and ultra-pure alumina powders without the addition of a temporarily binding agent placed in a graphite matrix with a diameter $25 \mathrm{~mm}$ and pressing at a pressure of $35 \mathrm{MPa}$ in vacuum. Then the SPS furnace chamber introduced argon, which acted as a protective gas and the sintering process were carried out at temperature about $1550^{\circ} \mathrm{C}$ for ten minutes duration of process. The SPS process was carried out in HP D 5 FCT Systeme GmbH furnace. Chamber and graphite dies for SPS apparatus are shown in Figure 5.

Sintering curves and parameters for various sintering methods are shown in Figure 6.

a)

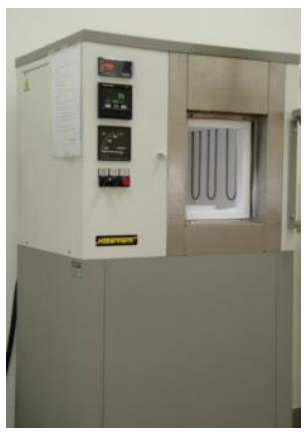

b)

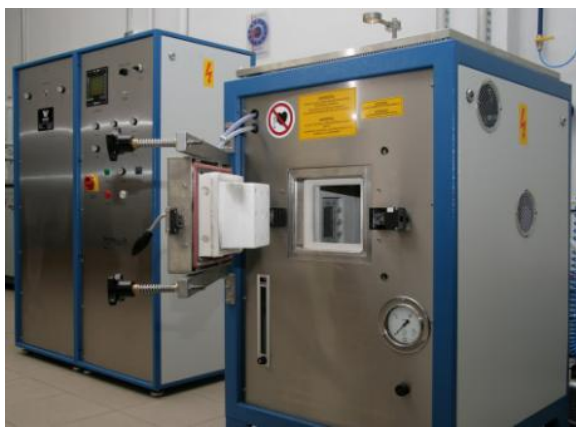

c)

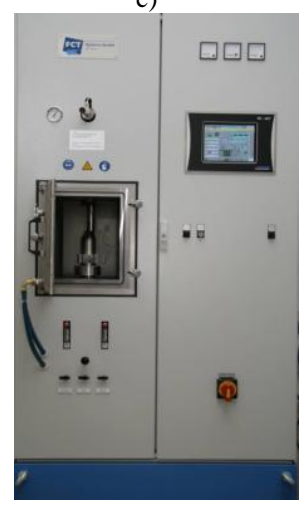

Figure 3. Equipments to sintering alumina ceramics: a) HT 16/18 Nabertherm electric furnace, b) MKH-4.8 Linn High Therm GmbH microwave furnace, c) HP D 5 FCT Systeme GmbH SPS furnace

a)

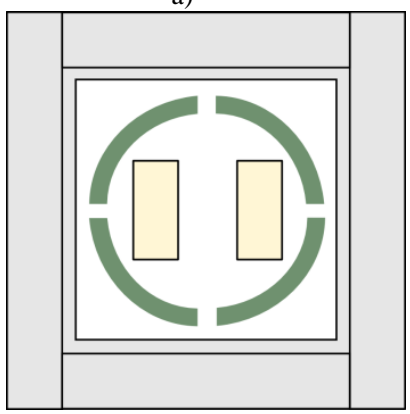

b)

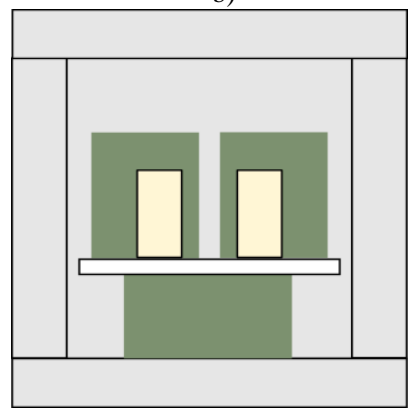

Figure 4. Alumina retort with the sintered samples surrounded by SiC susceptors (green color): a) view from the top, b) front view 

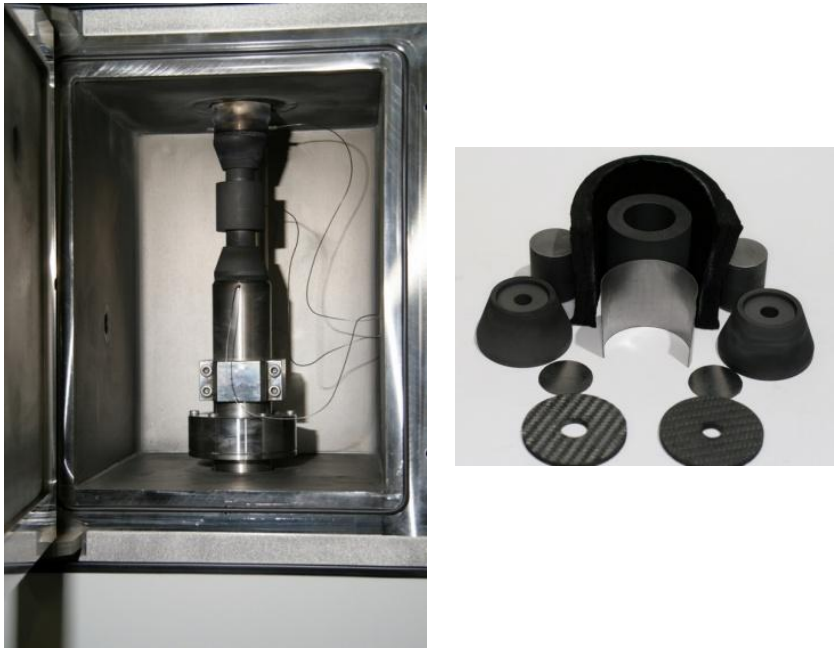

Figure 5. Graphite dies for SPS apparatus

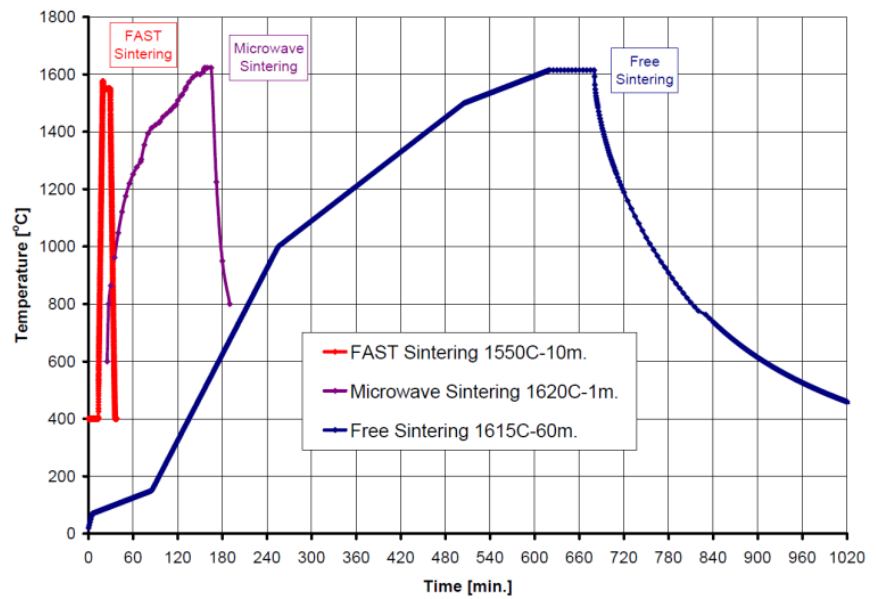

Figure 6. Sintering curves for various sintering methods of alumina

\subsection{METHODOLOGY}

After sintering, the materials were subjected to studies of their physical and mechanical properties. For this studies, metallographic specimens were prepared using Struers machines and polishing agents. The apparent density $\rho_{\rho}$ was measured using the hydrostatic method. Young's modulus of the sintered samples were also tested, using the ultrasonic method of measuring the transition speed of transverse and longitudinal waves, by means of a Panametrics Epoch III flaw detector. The hardness was determined by the Vickers method at a load of 98.7 $\mathrm{N}$ using a digital hardness tester (Future Tech. Corp. FM-7). For the materials after sintering SEM observation at the JEOL JSM-6460LV scanning electron microscope 
were carried out. In order to visualize the intergranular boundaries in the obtained sinters process of vacuum treating was carried out. Vacuum treating is more appropriate method from chemical etching for samples with fine structures. Vacuum treating process was carried out in $1450^{\circ} \mathrm{C}$ for 30 minutes in air using HT $16 / 18$ Nabertherm electric furnace.

On the basis of images from scanning electron microscope was performed quantitative analysis which allows to determine the degree of grain growth of alumina after sintering for prepared sinters depending on the chosen sintering methods. Our calculations are based on classic formulas of stereology for single-phase structure, which represent the microstructures visible in Figures 4,5 and 6. The microstructure of alumina samples have equiaxial grains of the same phase and existing of surfaces of grain boundaries additionally better shown through the process of thermal digestion. On the received microstructure was applied imaginable straight lines of equal length. At a section $\mathrm{T}$ by length $\mathrm{L}_{\mathrm{T}}$ counts of linear grains. If on the section $\mathrm{T}$ is $\mathrm{N}$ grains then the parameter $\mathrm{N}_{\mathrm{L}}$ is determined by the formula (1) [10]:

$$
N_{L}=\frac{N}{L_{T}}
$$

In turn the average particle length be calculated using the formula (2):

$$
\langle L\rangle=\frac{1}{N_{L}}
$$

Then the relative surface of the grains be calculated from Saltykov formula (3):

$$
\left\langle S_{V}\right\rangle=\frac{2}{\langle L\rangle}
$$

where: $N$ - numer of objects (grains or particles), $L_{T}$ - the length of a line section [mm], $N_{L}-$ the relative cardinality of the grains $\left[\mathrm{mm}^{-1}\right],\langle L\rangle$ - average length of grains $[\mathrm{mm}],\left\langle S_{V}\right\rangle-$ relative surface of grains $\left[\mathrm{mm}^{-1}\right]$

Then according to the scale of the pictures of microstructure average length of grains is converted to the real given in the $\mu \mathrm{m}$.

\section{RESULTS OF INVESTIGATIONS}

\subsection{MECHANICAL INVESTIGATIONS}

The results of the apparent density, Young's modulus and hardness measurements for alumina obtained by free-sintering, SPS and microwave sintering are presented in Table 1. During the conventional sintering all samples were sintered in duration of $60 \mathrm{~min}$ and variable sintering temperature, from $1615^{\circ} \mathrm{C}$ to $1665^{\circ} \mathrm{C}$. For the samples prepared from mixture I maximum density was reached at the level of $3.91 \mathrm{~g} / \mathrm{cm}^{3}$ and Young's modulus at the level of $380 \mathrm{GPa}$. In this case higher sintering temperature did not improve physicmechanical properties of the obtained sinters and hardness decreased with the growth of sintering temperature. Increasing the temperature of free sintering of high purity $\mathrm{Al}_{2} \mathrm{O}_{3}(\mathrm{Al}$ 600) samples led to the increase of density of the obtained material and Young's modulus. 
Hardness of the sample material grew simultaneously with the increase of sintering temperature.

In the case of applying of advanced sintering techniques microwave sintering and SPS obtained samples had a density, Young's modulus and hardness similar to those which are obtained for free sintered materials. However duration (1 $\mathrm{min}$ for microwave sintering, 10 min for SPS) of advanced sintering techniques is much shorter than free sintering.

Table 1. The results of apparent density, Young's modulus, hardness of obtained ceramic samples

\begin{tabular}{|c|c|c|c|c|}
\hline Mixture & Sample & $\begin{array}{c}\rho_{\rho}, \\
\mathrm{g}_{/} \mathrm{cm}^{3}\end{array}$ & $\begin{array}{c}\mathrm{E}, \\
\mathrm{GPa} \\
\end{array}$ & $\begin{array}{r}\text { HV1, } \\
\text { GPa }\end{array}$ \\
\hline \multicolumn{5}{|c|}{ Free sintering $1\left(1615^{\circ} \mathrm{C}, 60 \mathrm{~min}\right)$} \\
\hline $\mathrm{I}$ & 1 & 3.91 & 386 & 18.70 \\
\hline II & 2 & 3.54 & 279 & 12.00 \\
\hline \multicolumn{5}{|c|}{ Free sintering $2\left(1640^{\circ} \mathrm{C}, 60 \mathrm{~min}\right)$} \\
\hline $\mathrm{I}$ & 3 & 3.92 & 387 & 17.60 \\
\hline II & 4 & 3.68 & 312 & 13.30 \\
\hline \multicolumn{5}{|c|}{ Free sintering $3\left(1665^{\circ} \mathrm{C}, 60 \mathrm{~min}\right)$} \\
\hline $\mathrm{I}$ & 5 & 3.91 & 384 & 16.00 \\
\hline II & 6 & 3.75 & 329 & 14.60 \\
\hline \multicolumn{5}{|c|}{ Microwave sintering $1\left(1620^{\circ} \mathrm{C}, 1 \mathrm{~min}\right)$} \\
\hline $\mathrm{I}$ & 7 & 3.87 & 376 & 16.00 \\
\hline II & 8 & 3.83 & 379 & 16.10 \\
\hline \multicolumn{5}{|c|}{ Spark plasma sintering $1\left(1550^{\circ} \mathrm{C}, 10 \mathrm{~min}\right)$} \\
\hline I & 9 & 3.87 & 381 & 16.00 \\
\hline II & 10 & 3.83 & 362 & 17.00 \\
\hline
\end{tabular}

\subsection{MICROSTRUCTURAL INVESTIGATIONS}

Microstructure of selected samples prepared from mixture I and mixture II obtained by various sintering method are presented in Figure 7,8,9 respectively.

The average grain sizes of alumina obtained from independent measurements calculated according to the formulas (1-3) are presented in Table 2.

a)

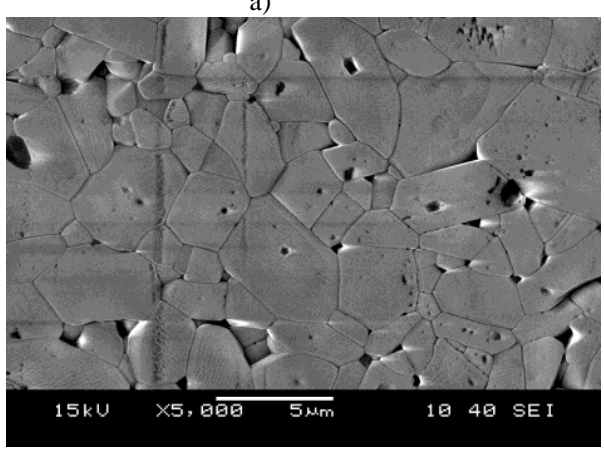

b)

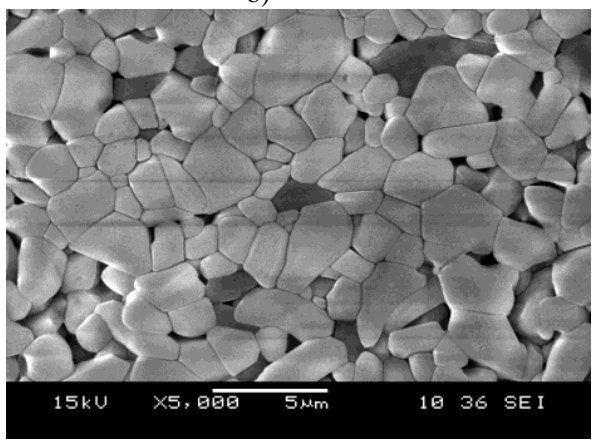

Figure 7. Microstructure of alumina obtained by free sintering at $1615^{\circ} \mathrm{C}$ : a) specimen 1 , b) specimen 2 
a)

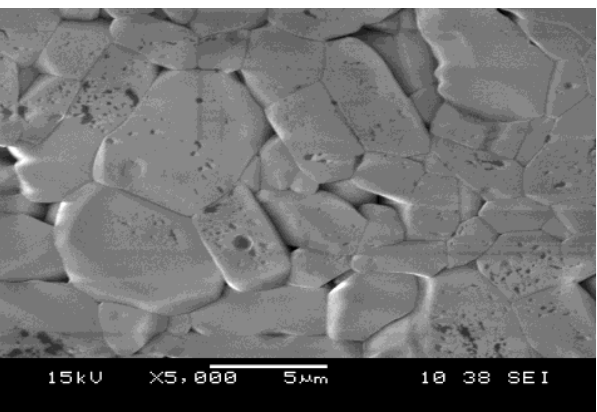

b)

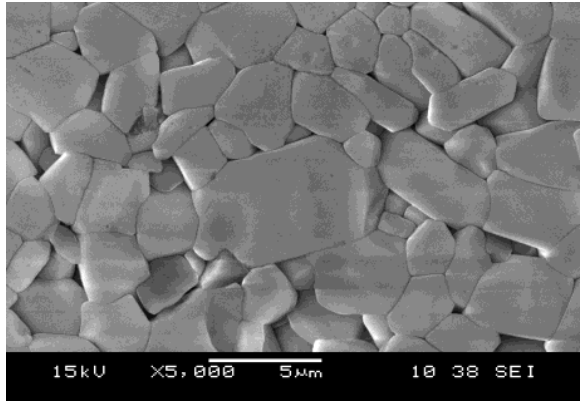

Figure 8 . Microstructure of alumina obtained by microwave sintering at $1620^{\circ} \mathrm{C}$ : a) specimen 7 , b) specimen 8

a)

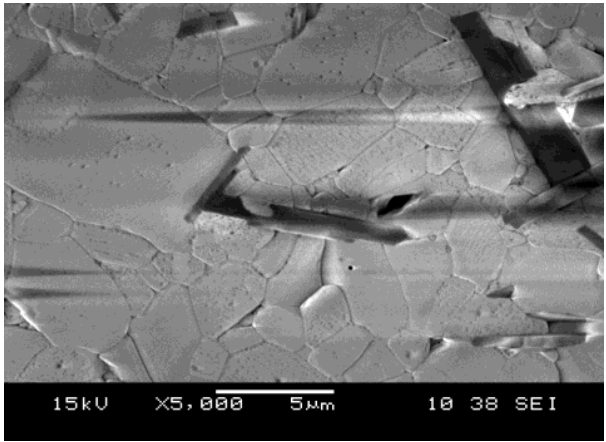

b)

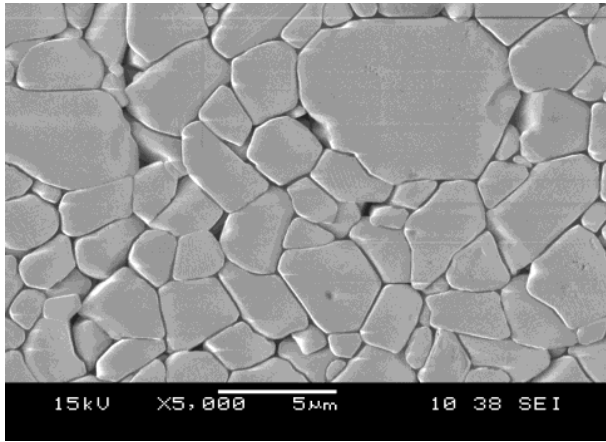

Figure 9. Microstructure of alumina obtained by SPS at $1550^{\circ} \mathrm{C}$ : a) specimen 9 , b) specimen 10

Table 2. Measurement results of grain sizes in obtained sinters of alumina

\begin{tabular}{|c|c|c|c|c|c|c|c|}
\hline Mixture & Sample & $N$ & $\begin{array}{c}N_{L}, \\
\mathrm{~mm}^{-1}\end{array}$ & $\begin{array}{c}\langle L\rangle, \\
\mathrm{mm}\end{array}$ & $\begin{array}{c}\left\langle S_{V}\right\rangle, \\
\mathrm{mm}^{-1}\end{array}$ & $\begin{array}{c}L, \\
\mu \mathrm{m}\end{array}$ & $\begin{array}{c}S_{V}, \\
\mu \mathrm{m}^{-1}\end{array}$ \\
\hline I & 1 & 13.6 & 0.05 & 19.7 & 0.10 & 1.86 & 0.009 \\
\hline II & 2 & 16.4 & 0.06 & 16.3 & 0.12 & 1.54 & 0.011 \\
\hline I & 7 & 8.6 & 0.03 & 31.2 & 0.06 & 2.94 & 0.006 \\
\hline II & 8 & 11.0 & 0.04 & 24.4 & 0.08 & 2.30 & 0.008 \\
\hline I & 9 & 9.2 & 0.04 & 24.4 & 0.08 & 2.30 & 0.008 \\
\hline II & 10 & 8.7 & 0.04 & 25.8 & 0.08 & 2.48 & 0.007 \\
\hline$N-$ number of objects (grains or particles), $N_{L}-$ the relative cardinality of the \\
grains, $\langle L\rangle$ \\
real geometrical sizes average length of grains, $\left\langle S_{V}\right\rangle-$ relative surface of grains, $L, S_{V}-$ \\
real
\end{tabular}

\section{CONCLUSION}

In this paper have been presented the methods of powder sintering of technical $\mathrm{Al}_{2} \mathrm{O}_{3}$ and extra pure $\mathrm{Al}_{2} \mathrm{O}_{3}$. Sintering was carried out by three different techniques: conventional free 
sintering, spark plasma sintering and microwave sintering. Density and Young's modulus in particular was assumed to be criterion of material densification. Hardness measurements supplemented the measurements performed on sintered samples. In the case of free sintering for samples of technical $\mathrm{Al}_{2} \mathrm{O}_{3}$, increasing the sintering temperature did not practically result in any change of material density and Young's modulus. In this case sintering can be carried out in lower temperature since too high temperature can lead to unfavorable grain growth. Increasing the sintering temperature resulted in the decrease of material hardness. Respectively, for samples made from high purity $\mathrm{Al}_{2} \mathrm{O}_{3}$, sample density, Young's modulus and hardness increased with the growth of sintering temperature. The sintering temperature of extra pure $\mathrm{Al}_{2} \mathrm{O}_{3}$ usually grows with the increase of its purity which was confirmed during conventional sintering.

The use of non-conventional sintering methods, such as spark plasma sintering and microwave sintering, contributes to obtaining a well-densified material with good physicalmechanical properties at relatively short sintering times.

Applied sintering methods allow to receive practically no porous microstructures of obtained samples with predominantly isometric grains of $\mathrm{Al}_{2} \mathrm{O}_{3}$. Microwave and SPS sintering methods did not prevent grains growth of $\mathrm{Al}_{2} \mathrm{O}_{3}$, and even resulted in their growth. Average length of grains of $\mathrm{Al}_{2} \mathrm{O}_{3}$ is $(\sim 2.95 \mu \mathrm{m})$ for microwave sintering and $(\sim 2.40 \mu \mathrm{m})$ for SPS.

\section{ACKNOWLEDGMENTS}

The research results were presented in the frame of the statute task (DS.12-3.1.1), carried out in Institute of Advanced Manufacturing Technology in Cracow.

\section{REFERENCES}

[1] TIANBEN G., HONGZHI L., Microwave sintering of $\mathrm{Al}_{2} \mathrm{O}_{3}-\mathrm{ZrO}_{2}-W C$-Co cermets, Journal of Wuhan University of Technology-Mater. Sci. Ed., Vol. 26, Issue 2, 2011, 289-291.

[2] SMUK B., SZUTKOWSKA M., WALTER J., Alumina ceramics with partially stabilized zirconia for cutting tools, Journal of Materials Processing Technology, Vol. 133, 2003, 195-198.

[3] RAO P., IWASA M., I. KONDOH I., Properties of low-temperature-sintered high purity $\alpha$-alumina ceramics, Journal of Materials Science Letters, Vol. 19, 2000, 543-545.

[4] RAJESWARI K., HAREESH U.S., SUBASRI R., CHAKRAVARTY D., Comparative evaluation of spark plasma (SPS), microwave (MWS), two stage sintering (TSS) and conventional sintering (CRH) on the densification and micro structural evolution of fully stabilized zirconia ceramics, Science of Sintering, Vol. 42, 2010, 259-267.

[5] HEUGUET R., MARINEL S., THUAULT A., BADEV A., Effects of the susceptor dielectric properties on the microwave sintering of alumina, Journal of the American Ceramic Society, Vol. 96, 2013, 3728-3736.

[6] PERT E., CARMEL Y., BIRNBOIM A., OLERUNYOLEMI T., GERSHON D., CALAME J., Temperature measurements during microwave processing: the significance of thermocouple effects, Journal of the American Ceramic Society, Vol. 84, 2001,1981-1986.

[7] WYŻGA P., JAWORSKA L., BUĆKO M., PUTYRA P., KALINKA A., Sintering of TiB ${ }_{2}-T i N$ nano- and micropowders, Composites, Vol. 1, 2011, 34-38.

[8] TOKITA M., Mechanism of spark plasma sintering, Proceedings of the 2000 Powder Metallurgy World Congress (Kyoto, Japan, November 2000), Edited by K.Kosuge and H.Nagai. Japanese Society of Powder and Powder Metallurgy, Kyoto, Japan, 2001, 729-732.

[9] KWON H., PARK D.H., PARK Y., SILVAIN J.F., KAWASAKI A., Spark plasma sintering behavior of pure aluminium depending on various sintering temperatures, Met. Mater. Int., Vol. 16, No. 1, 2010,71-75.

[10] WALA A., Mikroskopowe badania metalograficzne, Wyd. Uniwersytetu Śląskiego, 2004, Katowice. 